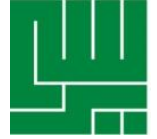

KATA KUNCI KEYWORDS

ABSTRAK

ABSTRACT

\section{Hubungan Antara Identitas Organisasi dan Perilaku Kerja Inovatif di Industri Kreatif: Studi pada Karyawan Perusahaan X}

\section{The Relationship Between Organizational Identity and Innovative Work Behavior in Creative Industry: A Study Among Emplyees of X Company}

\author{
Hanan Maria Hatta ${ }^{1} \&$ Endang Parahyanti ${ }^{2}$ \\ Fakultas Psikologi, Universitas Indonesia, Depok, Indonesia \\ E-mail: hnnmariah@gmail.com
}

Identitas organisasi, inovatif, industri kreatif

Organizational Identity, Innovative Work Behavior, Creative Industry

Penelitian ini bertujuan untuk melihat hubungan antara identitas organisasi dan perilaku kerja inovatif pada perusahaan $X$. Penelitian ini didasarkan pada pesatnya perkembangan dari industri kreatif. Pendekatan yang sesuai dalam menghadapi hal tersebut adalah pendekatan inovatif yang dapat memicu diterapkannya perilaku kerja inovatif dalam organisasi. Salah satu hal yang dapat memiliki hubungan dengan perilaku kerja inovatif adalah identitas organisasi. Identitas organisasi sendiri memiliki peranan penting dalam memandu perilaku kayawan yang diharapkan muncul. Terdapat total 401 karyawan perusahaan $X$ yang berpartisipasi dalam penelitian ini. Perusahaan $X$ merupakan perusahaan yang memiliki nilai inovatif dan bergerak dalam bidang industri kreatif dengan sub-kelompok penerbitan dan percetakan. Terdapat dua alat ukur yang digunakan dalam penelitian ini adalah Innovative Work Behavior Scale (Janssen, 2000) dan Organizational Identity Scale (Etikariena, 2015). Dengan menggunakan teknik analisis pearson product moment correlation, hasil penelitian menunjukkan bahwa tidak ditemukan adanya hubungan yang signifikan antara identitas organisasi dan perilaku kerja inovatif $(r=0,063, p>0,05)$.

This research was conducted to see the relationship between organizational identity and innovative work behavior in $X$ Company. It was based on the rapid development of creative industry. One of the approaches to deal with that condition is innovation, which can leads innovative work behavior in organization. One of the factors that can have a correlation with innovative work behavior is organizational identity. Organizational identity itself has a significant role to guide employee's behaviors. There were 401 employees of X Company that has participated in this research. $X$ Company is an organization that has innovative 
value and runs in creative industry area, specifically printing and publishing sub-sector. There were two instruments used in this research, innovative work behavior scale (Janssen, 2000) and organizational identity scale (Etikariena, 2015). Using pearson product moment correlation to analyze the data, the result shows us that there were no significant correlation found among organizational identity and innovative work behavior $(r=0,063, p$ $>0,05)$.

\section{PENDAHULUAN}

Pada saat ini, terdapat tuntutan untuk mencapai tingkat perkembangan ekonomi sesuai target dan juga memenuhi kriteria akan adanya perkembangan yang berkelanjutan (Moore, 2014). Salah satu pendekatan untuk mencapai tuntutan tersebut adalah dengan keberadaan industri kreatif yang memiliki kesempatan pertumbuhan tinggi, terutama untuk negara berkembang (UNCTAD, 2010). Darwis (2013) menyatakan bahwa sebagai salah satu aktivitas ekonomi yang merefleksikan potensi dan produktivitas dari sumber daya lokal, industri kreatif juga dinyatakan memiliki peran penting dalam membentuk nilai-nilai tambah melalui eksistensi dari produk atau jasa kreatif.

Data dari Kemenparekraf (2014) menunjukkan bahwa industri kreatif di Indonesia mengalami rata-rata pertumbuhan sebesar $12,2 \%$ setiap tahunnya. Sebagai industri yang memiliki perkembangan pesat, industri kreatif pun menjadi salah satu industri dengan daya saing tinggi dalam skala nasional juga skala internasional (Darwis, 2013). Miron, Erez, dan Naveh, (dalam Schermuly, Meyer, \& Dammer, 2013) mengatakan bahwa untuk dapat mempertahankan tingkat kompetitif dalam lingkungan bisnis global, suatu organisasi perlu terus menerus mengembangkan produk dan jasa inovatif.

Produk dan jasa inovatif sendiri dapat tercipta dengan adanya inovasi.
Oster (dalam Moon, 2014) mengatakan bahwa inovasi dan efisiensi merupakan hal yang penting jika suatu organisasi ingin bertahan. Selain dapat membuat organisasi bertahan dalam jangka panjang, inovasi juga berpengaruh terhadap kesuksesan organisasi (Neal, dalam Leong \& Rasli, 2013). Dikatakan pula oleh Peters dan Waterman (dalam Kheng, June, \& Mahmood, 2013) bahwa inovasi sering kali digunakan oleh organisasi sebagai suatu cara agar organisasi dapat bekerja dengan sukses, efektif, dan kompetitif dalam lingkungan bisnis yang dinamis. Ketika inovasi dilakukan dalam organisasi, maka hal tersebut dapat dikatakan sebagai perilaku kerja inovatif (Waenink, 2012). Perilaku kerja inovatif didefinisikan sebagai perilaku individu yang bertujuan untuk menginisiasikan atau memperkenalkan dengan sengaja suatu ide, proses, produk atau prosedur yang baru dan berguna (Jong \& Hartog, 2008).

Perilaku kerja inovatif dipengaruhi oleh beberapa faktor. Dinyatakan oleh Dhalla (2007) bahwa nilai dan kepercayaan organisasi merupakan hal krusial dalam membentuk sikap, minat, dan motivasi karyawan terhadap inovasi. Hal tersebut tidak akan dapat muncul dengan baik jika karyawan tidak paham dan tidak dapat mempersepsikan dengan baik nilai utama bagi organisasi tempat mereka bekerja. Pemahaman dan persepsi karyawan tersebut dapat dibentuk melalui identitas organisasi. Jika karyawan paham bahwa nilai ataupun karakteristik inovasi 
merupakan yang utama (central) dan bersifat kontinu atau telah berlangsung secara terus menerus (continuity), maka perilaku kerja inovatif akan menjadi hal yang normal dilakukan dalam keseharian di organisasi (Gawer \& Phillips, 2013).

$$
\text { Ashforth dan Mael (1996) }
$$

menyatakan bahwa istilah identitas organisasi sendiri mengacu pada karakteristik organisasi yang utama (central), telah berlangsung lama (continuity), dan karakteristik organisasi yang berbeda dengan organisasi lainnya (disctinctive). Identitas organisasi didefinisikan sebagai persepsi individu yang tergabung dalam organisasi tersebut terhadap karakteristik organisasi (Albert \& Whetten, dalam Dhalla, 2007). Identitas organisasi tersebut dapat menjadi suatu panduan bagi karyawan dalam menginterpretasi suatu peristiwa dan pada akhirnya juga akan berpengaruh pada tindakan yang akan diambil oleh karyawan (Dhalla, 2007). Bentuk panduan dalam interpretasi ini dapat menjelaskan pertanyaan seperti 'Apa maksud dan cerita dibalik adanya suatu kegiatan' dalam konteks pekerjaan sehari-hari, dan kemudian seringkali dilanjutkan dengan pertanyaan 'Apa yang sebaiknya dilakukan menghadapi kegiatan tersebut' (Weick, Sutcliffe, \& Obstfeld, 2005). Dengan kata lain, ketika karyawan mempersepsikan dan paham bahwa organisasi tempat dia bekerja membutuhkan adanya perilaku inovasi agar organisasi dapat terus bertahan dan tetap kompetitif, maka ia pun akan menjadikan pemahaman mereka sebagai panduan mengenai perilaku yang tepat untuk ditunjukkan. Dalam penelitian ini, konteks perilaku yang menjadi fokus utama adalah perilaku kerja inovatif.

Populasi yang akan diambil oleh peneliti adalah organisasi yang bergerak pada industri kreatif. Hal ini dikarenakan industri kreatif secara jelas menerapkan karakteristik inovasi dalam lingkup pekerjaannya sehari-hari. Penelitian sebelumnya sendiri belum ada yang mengaitkan identitas organisasi dan perilaku kerja inovatif pada konteks industri kreatif. Penelitian ini dilakukan pada perusahaan $X$ yang memiliki karakteristik inovasi dan termasuk dalam bidang industri kreatif dengan sub-sektor penerbitan dan percetakan.

\section{Perilaku Kerja Inovatif}

Definisi perilaku kerja inovatif terus berkembang dari masa ke masa. West dan Farr (1989) menyatakan bahwa perilaku kerja inovatif adalah suatu usaha yang dilakukan dengan sengaja dalam mengenalkan dan mengaplikasikan ide, proses, produk, maupun prosedur yang baru ataupun adaptasi dalam peran kerja kelompok atau organisasi yang secara signifikan di desain untuk memberikan manfaat pada performa kerja kelompok, organisasi, maupun lingkungan dengan skala yang lebih luas. Selanjutnya, Scott dan Bruce (1994) menyatakan bahwa perilaku kerja inovatif merupakan suatu rangkaian proses dengan banyak tahapan. Scott dan Bruce (1994) menekankan pada pentingnya implementasi ide pada tahapan perilaku kerja inovatif. Definisi yang dinyatakan oleh West dan Farr (1989) serta Scott dan Bruce (1994) kemudian diadaptasi oleh Janssen (2000), sehingga perilaku kerja inovatif didefinisikan sebagai perilaku dengan banyak tahapan (idea generation, idea promotion, idea realization), yang dilakukan dengan sengaja dan bertujuan untuk memberikan manfaat pada kelompok maupun organisasi.

Pada tahap generasi ide (idea generation), individu mulai mengenali adanya suatu masalah dan melakukan pengembangan atas ide maupun solusi baru atau adaptasi dari yang telah ada sebelumnya. Hal-hal yang biasanya memicu adanya proses generasi ide ini 
adalah adanya masalah pekerjaan yang di anggap ada oleh individu, adanya inkongruensi, diskontinu, dan tren yang sedang berjalan (Scott dan Bruce, 1994). Pada tahap idea promotion, individu berusaha mencari pihak yang dapat mendukung individu tersebut untuk merealisasikan ide yang ia miliki (Janssen, 2000). Sedangkan pada tahap idea realization, individu akan merealisasikan ide yang ia miliki dengan cara memproduksi suatu protoipe atau model yang dapat disentuh atau dirasakan (Kanter, 1988; Scott \& Bruce, 1994; Janssen, 2000).

Terdapat banyak faktor yang memengaruhi perilaku kerja inovatif. Jong dan Hartog (2008) menyatakan bahwa terdapat tiga faktor yang memengaruhi perilaku kerja inovatif, yaitu tipe pemimpin partisipatif (Rickards \& Moger, 2006), motivasi intrinsik (Amablie, 1983), serta kontak dengan pihak luar organisasi (Kimberly \& Evanisko, 1981; Kanter, 1988). Selain faktor tersebut, Dörner (2012) membagi faktor-faktor yang memengaruhi perilaku kerja inovatif menjadi dua bagian, yaitu faktor organisasi dan faktor individual. Faktor yang termasuk dalam faktor individual adalah kecenderungan untuk berinovasi, ketertarikan intrinsik, dan orientasi untuk keahlian. Sedangkan faktor organisasi yang berpengaruh terhadap perilaku kerja inovatif adalah perilaku atasan, tipe pemimpin transformasional dan leader member exchange, budaya organisasi, iklim organisasi, dukungan terhadap inovasi dan job autonomy, tantangan pekerjaan, dan task and goal interdependence. Identitas organisasi pun dapat dikategorikan sebagai salah satu faktor organisasi yang memengaruhi perilaku kerja inovatif dikarenakan persepsi yang dimiliki karyawan terhadap identitas organisasi berkaitan erat dengan karakteristik yang ada di organisasi.

\section{Identitas Organisasi}

Konsep identitas organisasi pada awalnya dicetuskan oleh Albert dan Whetten pada tahun 1985. Albert dan Whetten (dalam Witting, 2006) menyatakan dalam sebuah kalimat 'How do we see ourselves'. Kalimat lain yang juga dinyatakan oleh Albert dan Whetten (1985 dalam Gioia, Schultz, \& Corley, 2000) sehubungan dengan identitas organisasi adalah 'who we are as an organization'. Albert dan Whetten (dalam Witting, 2006) mendefinisikan identitas organisasi sebagai suatu hal yang dipersepsikan karyawan sebagai karakter organisasi yang bersifat utama (centrality), kontinuitas (continuity), dan berbeda (distinctive) dari karakter organisasi lain. Gioia, Schultz, \& Corley (2000) menambahkan bahwa identitas organisasi merupakan pemahaman kolektif dari karyawan organisasi mengenai ketiga karakter yang telah disebutkan sebelumnya. Albert dan Whetten (dalam Ashforth \& Mael, 1996) juga menyatakan bahwa identitas organisasi merupakan sumber dari stabilitas dan dasar dari tindakan yang dapat diambil oleh karyawan.

Berdasarkan berbagai definsi tersebut, definisi yang digunakan dalam penelitian ini merupakan definisi yang diajukan oleh Gioia, Schultz, dan Corley (2000) yang merupakan adaptasi dari definisi yang dinyatakan oleh Albert dan Whetten (1985). Oleh karena itu, definisi identitas organisasi yang digunakan adalah suatu hal yang dipersepsikan karyawan sebagai karakter organisasi yang bersifat utama (centrality), kontinuitas (continuity), dan berbeda (distinctive) dari karakter organisasi lain, dan persepsi karyawan yang ada merupakan pemahaman kolektif karyawan.

Ketiga karakteristik identitas organisasi yang ada yaitu centrality, continuity, dan distinctive secara lebih 
lanjut dipaparkan oleh Ashforth dan Mael (1996). Centrality mengacu pada konsepsi utama yang memiliki kecenderungan untuk dapat berelaborasi dan berhubungan dengan kognisi, perilaku, dan juga afeksi. Dapat dikatakan bahwa yang dimaksud akan karakter utama merujuk pada suatu sistem yang konsisten secara internal. Sistem ini terdiri dari kepercayaan, nilai, dan juga norma yang akan mengarahkan agar tindakan-tindakan yang diambil karyawan organisasi sesuai dengan misi organisasi. Karakteristik continuity merujuk pada kontinuitas dan stabilitas. kontinuitas ini menjadikan organisasi mendapatkan suatu gambaran akan koherensi pada masa lalu dan membangun suatu arahan yang jelas pada masa depan. Identitas yang bersifat kontinuitas ini merupakan hal yang penting bagi kesuksesan jangka panjang (Albert \& Whetten, dalam Gioia, Schultz, \& Corley, 2000). Karakteristik terakhir adalah karakteristik distinctive. Karakteristik tersebut merujuk pada hal yang membedakan atau suatu hal yang menjadi perbandingan dengan organisasi lain. Adanya karakteristik yang membedakan suatu organisasi dengan organisasi lain menjadi suatu hal yang kritikal karena karyawan akan menjustifikasi hal ini dengan eksistensi organisasi mereka, hingga pada akhirnya hal ini akan memengaruhi identifikasi karyawan pada organisasi nya (Martin, Feldman, Hatch, \& Sitkin, dalam Ashforth \& Mael, 1996). Dinyatakan pula oleh Abrams dan Hogg (dalam Whetten, 2006) bahwa karakteristik pembeda dari organisasi akan berpengaruh terhadap harga diri yang tinggi.

Identitas organisasi memiliki banyak dampak positif. Pada level organisasi, identitas organisasi dapat berperan dalam meningkatkan efektivitas dan performa organisasi (Stimpert,
Gustafson, \& Sarason, dalam Witting, 2006). Lin (2004) menyatakan bahwa identitas organisasi menjadi suatu hal yang penting karena hal tersebut dapat memengaruhi tindakan, interpretasi, dan pengambilan keputusan bagi organisasi serta anggotanya. Ditambahkan pula oleh Lin (2004) bahwa identitas akan menjadi suatu panduan dalam menjelaskan emosi yang dimiliki anggota organisasi dalam menghadapi isu-isu organisasi yang ada. Barney dan Stewart (dalam Witting, 2006) menyatakan bahwa identitas organisasi dapat berperan dalam pengambilan keputusan oleh organisasi dikarenakan mereka melihat identitas organisasi sebagai suatu alat yang memfasilitasi organisasi dalam membentuk suatu konsep dan juga memfasilitasi organisasi dalam implementasi tindakan strategis organisasi.

\section{Industri Kreatif}

Berdasarkan Kementerian Perdagangan Indonesia, industri kreatif didefinisikan sebagai industri yang berasal dari pemanfaatan kreativitas, keterampilan, serta bakat individu untuk menciptakan kesejahteraan serta lapangan pekerjaan melalui penciptaan dan pemanfaatan daya kreasi dan daya cipta individu tersebu (dalam Parman, Subagiyo, Chairi, Erwidodo, Kresnarini, \& Suseno, 2008). Industri kreatif diklasifikasikan kedalam 14 bidang oleh kementerian perdagangan Indonesia (dalam Parman dkk., 2008), yaitu periklanan, arsitektur, pasar barang seni, kerajinan tangan, desain, fesyen, videofilm-dan fotografi, permainan interaktif, musik, seni pertunjukkan, penerbitan dan percetakan, teknologi, televisi dan radio, serta riset dan pengembangan. Ditambahkan oleh Utami dan Lantu (2012) bahwa sejak tahun 2011, kuliner menjadi salah satu bidang yang termasuk dalam ranah industri kreatif. 


\section{Dinamika Hubungan Identitas Organisasi dan Perilaku Kerja Inovatif}

Inovasi merupakan hal yang penting jika suatu organisasi ingin bertahan dalam jangka panjang (Oster, dalam Moon, 2014), tetap dapat kompetitif pada kompetitor lainnya dalam lingkungan bisnis yang dinamis (Peters \& Waterman, dalam Kheng, June, \& Mahmood, 2013), juga meningkatkan performa (Binnewies \& Gromer, dalam Shalley, Zhou, \& Oldham, 2004). Ketika inovasi ini dilakukan dalam lingkup organisasi, maka hal tersebut dikatakan sebagai perilaku kerja inovatif (Waenink, 2012).

Melihat perilaku kerja inovatif merupakan salah satu hal yang krusial agar organisasi dapat bertahan, penting untuk meninjau faktor-faktor yang memiliki hubungan maupun pengaruh terhadap perilaku kerja inovatif. Terdapat faktor identitas organisasi yang dapat digolongkan sebagai salah satu faktor organisasi. Identitas organisasi ini menekankan pada persepsi yang dimiliki oleh anggota organisasi terhadap nilai ataupun karakteristik organisasi. Ketika nilai-nilai ataupun karakteristik organisasi tersebut tidak dapat dipahami dan dipersepsikan dengan baik oleh karyawan organisasi, maka nilai-nilai ataupun karakteristik tersebut tidak dapat diterapkan dengan baik oleh karyawan organisasi (Dhalla, 2007). Ketika karyawan memiliki identitas organisasi yang baik, dalam arti dapat paham dan memiliki persepsi yang baik akan karakteristik organisasi, maka hal tersebut dapat menjadi suatu panduan bagi karyawan organisasi mengenai perilaku apa yang kemudian tepat untuk dimunculkan agar sesuai dengan nilai dan karakteristik tersebut.

Berdasarkan hal tersebut, identitas organisasi merupakan hal yang penting dalam memandu karyawan nya memunculkan perilaku yang diharapkan oleh organisasi. Dalam konteks ini, maka peneliti menduga bahwa identitas organisasi dapat memandu karyawan untuk memunculkan perilaku kerja inovatif yang dapat membawa banyak keunggulan positif bagi organisasi.

\section{METODE PENELITIAN}

Berdasarkan aplikasi penelitian, penelitian ini termasuk dalam penelitian terapan dikarenakan informasi yang didapatkan bisa bemanfaat dan diaplikasikan untuk meningkatkan perilaku kerja inovatif. Berdasarkan tujuan penelitian, penelitian ini termasuk ke dalam tipe penelitian korelasional karena menguji hubungan antar variabel penelitian yaitu identitas organisasi dan perilaku kerja inovatif. Sedangkan berdasarkan tipe informasi, penelitian ini termasuk penelitian kuantitatif yang didasarkan pada mengukur variabel untuk mendapatkan skor berbentuk numerik.

Dari segi desain penelitian, penelitian ini termasuk dalam crosssectional study design dikarenakan peneliti hanya melakukan kontak dengan responden sebanyak satu kali, yaitu ketika mengambil data. Penelitian ini juga termasuk dalam retrospective study design dikarenakan penelitian ini melihat suatu fenomena, situasi, masalah, ataupun isu yang telah terjadi. Sedangkan dari sifat penelitian, penelitian ini termasuk dalam penelitian non- eksperimental dikarenakan penelitia tidak memberikan manipulasi apapun dalam penelitian.

Responden penelitian merupakan karyawan tetap dengan masa kerja minimal 1 tahun, dari perusahaan $X$ yang bergerak dalam industri kreatif dengan subsektor penerbitan dan percetkan, serta menerapkan nilai inovatif pada kesehariannya. Dari total 538 responden 
yang berpartisipasi, terdapat 401 data responden yang dapat diolah.

Terdapat variabel data kontrol dalam penelitian ini, yaitu status karyawan, masa bekerja, jenjang pendidikan, level jabatan, jenis kelamin, usia responden, dan departemen tempat responden bekerja.

Instrumen penelitian yang digunakan berbentuk kuesioner dan telah diuji coba reliabilitas dengan teknik cronbach alpha. Instrumen penelitian perilaku kerja inovatif menggunakan alat ukur Janssen (2000) yang terdapat total 9 item favorable $(\mathrm{a}=.936)$ dengan 3 item pada masing-masing dimensi. Skala likert type yang digunakan memiliki 6 rentang jawaban yaitu dari "belum pernah sama sekali" hingga "selalu menampilkan". Sedangkan untuk instrumen penelitian identitas organisasi menggunakan alat ukur Etikariena (2015) yang diadaptasi dan dikembangkan dari Aaker (1997, dalam Witting, 2006). Terdapat total 8 item (a= .749) dengan masing-masing 3 item untuk karakteristik centrality dan distinctiveness, serta 2 item untuk karakteristik continuity. Skala likert type yang digunakan memiliki 6 rentang jawaban yaitu dari "tidak sesuai" hingga "sangat sesuai".

Setelah proses pengambilan data selesai, dilakukan input data ke program pengolahan data SPSS (Statistical Package for Social Science). Teknik analisis yang digunakan adalah pearson product moment untuk melihat hubungan antar variabel, independent sample t-test untuk melihat perbedaan rata-rata pada dua kelompok, dan one way analysis of variance untuk melihat perbedaan ratarata pada dua kelompok atau lebih.

\section{ANALISA DAN HASIL}

Berdasarkan analisis deskriptif, didapatkan gambaran bahwa dari sejumlah 401 responden penelitian, 61\% adalah responden laki-laki, $78 \%$ nya memiliki rentang usia 25 hingga 44 tahun, $71 \%$ memiliki jenjang pendidikan minimum S1, 53\% responden telah bekerja selama lebih dari sepuluh tahun, 65\% responden memiliki jabatan pada level staff, dan $34 \%$ responden berasal dari departemen bisnis.

Variabel penelitian diukur melalui enam skala likert type. Pada variabel perilaku kerja inovatif, terdapat total sembilan item sehingga range nilai yang mungkin dimiliki partisipan adalah sembilan hingga 54. Berdasarkan hasil olah data, didapatkan rata-rata skor total responden sebesar 29.71 ( $\mathrm{SD}=9.557)$. Sedangkan pada variabel identitas organisasi, rentang skor yang didapatkan adalah delapan hingga 48. Berdasarkan hasil olah data, didapatkan rata- rata skor total responden sebesar 30.83 $(\mathrm{SD}=5.544)$.

Berdasarkan analisis data korelasi menggunakan pearson product moment, tidak ditemukan adanya hubungan yang signifikan antara variabel identitas organisasi dan perilaku kerja inovatif $(\mathrm{r}=.063 ; p>.05)$. Hal ini menunjukkan bahwa $\mathrm{H} 1$ ditolak dan $\mathrm{H} 0$ diterima.

Walaupun identitas organisasi merupakan variabel unidimensional, peneliti juga berusaha melihat karakteristik identitas organisasi apa yang memiliki hubungan paling kuat dengan perilaku kerja inovatif. Berdasarkan uji statistik, tidak ditemukan adanya hubungan yang signifikan antara karakteristik centrality dan perilaku kerja inovatif $(r=.024$; $p>.05)$, begitu pula hubungan antara karakteristik continuity dan perilaku kerja inovatif $(\mathrm{r}=-.012 ; p>.05)$, dan hubungan antara karakteristik distinctiveness dan perilaku kerja inovatif $(\mathrm{r}=.073 ; p>.05)$.

Peneliti juga melihat perbedaan rata-rata kelompok mengenai perilaku 
kerja inovatif berdasarkan data demografis responden. Berdasarkan analisis data independent sample t-test dan one way analysis of variance, terdapat empat kelompok yang memiliki perbedaan rata- rata kelompok yang signifikan. Keempat kelompok tersebut adalah jenis kelamin $(\mathrm{t}=4.806 ; p<.05)$, pendidikan $(\mathrm{t}=5.582 ; p<.05)$, jabatan $(\mathrm{t}=$ $.032 ; p<.05)$, dan departemen $(\mathrm{t}=2.810$; $p<.05)$.

\section{DISKUSI}

Berdasarkan analisis data, didapatkan kesimpulan bahwa identitas organisasi tidak memiliki hubungan dengan perilaku kerja inovatif. Chochlakis dan Pseirdis (dalam Arif, Zubair, \& Manzoor, 2005) menyatakan bahwa faktor yang lebih memengaruhi perilaku kerja inovatif adalah faktor internal individu dan juga faktor karakteristik pekerjaan. Hal inilah yang dapat menjadi salah satu alasan mengapa identitas organisasi yang termasuk dalam faktor organisasi tidak memiliki hubungan yang signifikan terhadap perilaku kerja inovatif.

Gioia, Schultz, dan Corley (2000) menyatakan bahwa identitas organisasi dapat menjadi suatu panduan bagi tingkah laku yang tepat untuk dimunculkan karyawan. Akan tetapi, karyawan perusahaan $\mathrm{X}$ sepertinya belum memiliki persepsi yang sesuai, bahwa inovasi menjadi salah satu karakteristik utama bagi perusahaan X. Hal ini menyebabkan karyawan pada perusahaan $\mathrm{X}$ tidak menjadikan identitas organisasi yang ada sebagai salah satu faktor yang berhubungan maupun memiliki pengaruh terhadap perilaku kerja inovatif. Berdasarkan hasil data informal yang diperoleh peneliti, didapatkan hasil bahwa karyawan $\mathrm{X}$ mengetahui dan menyebutkan inovasi sebagai salah satu karakteristik utama perusahaan $\mathrm{X}$, namun karyawan $\mathrm{X}$ seperti nya belum memahami lebih dalam inovasi seperti apa yang dimaksud oleh perusahaan $\mathrm{X}$.

Raymond (dalam Gawer \& Phillips, 2013) menyatakan bahwa agar karyawan paham dengan nilai dan karakteristik utama perusahaan, perlu adanya advokasi mengenai nilai dan karakteristik organisasi tersebut. Adanya advokasi ini juga perlu untuk ditindaklanjuti dengan diterapkannya nilai dan karakteristik tersebut pada lingkup pekerjaan sehari-hari, sehingga nilai dan karakteristik yang ada semakin dimaknai oleh karyawan (Chesbrough, dalam Gawer \& Phillips, 2013). Ketika nilai dan karakteristik tersebut telah dipahami dan dipersepsi dengan baik oleh karyawan, maka nilai dan karakteristik tersebut dapat menjadi panduan bagi tingkah laku yang tepat untuk dimunculkan karyawan (Gioia, Schultz, \& Corley, 2000).

Tercantumnya inovasi sebagai nilai dan atau karakteristik utama bagi perusahaan $\mathrm{X}$ menandakan bahwa perusahaan $\mathrm{X}$ berusaha untuk menggunakan identitas organisasi sebagai salah satu strategi perusahaan agar dapat bertahan dalam jangka panjang. Sesuai dengan pernyataan Hoholm dan Strønen (2011) yang menyatakan bahwa identitas organisasi memiliki peranan penting dalam memengaruhi strategi perusahaan. Namun seperti yang telah dipaparkan pada paragraf sebelumnya, karyawan perusahaan $\mathrm{X}$ tidak menganggap inovasi sebagai salah satu strategi perusahaan yang dapat menjadikan perusahaan $\mathrm{X}$ lebih kompetitif dan memiliki eksistensi jangka panjang.

Dikatakan oleh Ellonen, Blomquist, dan Puumalainen (dalam Hoholm \& Strønen, 2011) bahwa adanya kepercayaan terhadap organisasi (manajemen) dan juga institusi (sistem organisasi, praktik sumber daya 
manusia) memiliki pengaruh yang positif terhadap inovasi organisasi. Ketika karyawan memiliki persepsi, dan percaya bahwa perusahaan tidak mendukung adanya perilaku kerja inovatif, maka karyawan pun tidak akan menunjukkan perilaku kerja inovatif. Faktor dukungan terhadap inovasi sendiri menjadi salah satu faktor yang memengaruhi perilaku kerja inovatif (Dörner, 2012; Oukes, 2010). Pada kasus perusahaan $\mathrm{X}$, karyawan perusahaan $\mathrm{X}$ menyadari bahwa inovasi merupakan hal yang penting agar perusahaan $\mathrm{X}$ dapat bertahan dalam menghadapi ketatnya persaingan pada masa ini, namun, mereka menganggap bahwa perusahaan $\mathrm{X}$ tidak memberikan dukungan yang optimal pada karyawannya ketika karyawan mencoba untuk menampilkan perilaku kerja inovatif. Hal ini kemudian memengaruhi persepsi dan kepercayaan karyawan akan apakah inovasi benarbenar menjadi suatu hal yang esensial bagi perusahaan $X$.

Witting (2006) melakukan penelitian yang mengukur masingmasing karakteristik dari identitas organisasi terhadap beberapa variabel seperti identifikasi organisasi, perilaku, sikap, dan pengetahuan karyawan akan organisasi. Berdasarkan hasil penelitian tersebut, ditemukan bahwa karakteristik centrality berkorelasi positif dengan pengetahuan karyawan akan organisasi dan sikap mereka terhadap hal tersebut. Semakin suatu karyawan mempersepsikan dengan baik nilai utama dari organisasi, semakin mereka mengetahui tujuan utama dari organisasi dan semakin positif sikap yang mereka tunjukkan terhadap organisasi tersebut. Karakteristik centrality hanya terbatas memengaruhi pengetahuan karyawan dan sikap, namun tidak memengaruhi perilaku karyawan. Hal ini sesuai dengan penelitian ini, khususnya karakteristik centrality tidak memiliki hubungan dengan perilaku kerja inovatif.

Karakteristik kedua adalah continuity. Witting (2006) menemukan adanya korelasi negatif antara karakteristik continuity dan perilaku kerja inovatif. Witting (2006) menyatakan bahwa adanya discontinuity pada karakteristik organisasi justru memiliki hubungan positif terhadap perilaku karyawan yang dapat mendukung tercapainya tujuan organisasi. Hal ini sejalan dengan apa yang dinyatakan oleh Gioia, Schultz, dan Corley (2000) bahwa identitas organisasi dapat bersifat discontinuity, yaitu organisasi harus dapat mengorganisir stabilitas dan perubahan tersebut sebagai respon organisasi terhadap lingkungan yang terus berubah. Menanggapi hal ini, Whetten (dalam Gioia, Schultz, \& Corley, 2000) menyatakan bahwa ketika nilai atau karakteristik dari identitas ini berubah, maka perubahan yang ada tidak akan terjadi secara signifikan dan tetap akan mengacu pada nilai atau karakteristik awal.

Pada karakteristik distinctive, Witting (2006) tidak menemukan korelasi apapun dengan dependen variabel yang ada. Begitu pula pada penelitian ini yang tidak menemukan adanya korelasi signifikan antara karakteristik distinctive dengan perilaku kerja inovatif. Peneliti menduga bahwa hal ini dikarenakan karyawan tidak menjadikan karakteristik distinctive sebagai panduan mereka dalam menunjukkan perilaku kerja inovatif. Karyawan akan lebih menunjukkan perilaku kerja inovatif dikarenakan adanya faktor lain yang berperan, tidak peduli suatu karakter organisasi yang berbeda dari organisasi lain dipersepsikan secara baik atau tidak.

Dari sisi struktur jabatan sendiri, perusahaan $X$ termasuk dalam perusahaan yang memiliki banyak 
tingkatan struktur jabatan. Dikatakan oleh Harris (2002) bahwa organisasi dengan struktur yang datar, yaitu karyawan pada organisasi yang tidak memiliki banyak struktur jabatan memiliki kecenderungan untuk lebih memunculkan perilaku kerja inovatif. Hal ini dikarenakan struktur jabatan yang datar lebih memungkinkan karyawan memiliki kebebasan yang lebih dalam memunculkan perilaku kerja inovatif. Kebebasan disini berarti bahwa karyawan tidak perlu meminta banyak persetujuan dari atasan berdasarkan struktur jabatan yang ada ketika karyawan ingin memunculkan perilaku kerja inovatif. Oleh karena itu, dapat dikatakan bahwa perusahaan $\mathrm{X}$ yang memiliki banyak tingkatan struktur menjadi salah satu hal yang memengaruhi perilaku kerja inovatif yang dimunculkan karyawan perusahaan $\mathrm{X}$.

Faktor lain yang juga memiliki pengaruh terhadap perilaku kerja inovatif adalah ukuran organisasi (Zerfass \& Huch, dalam Arif, Zubair, \& Manzoor, 2012). Sebagai perusahaan yang termasuk dalam bidang penerbitan dan percetakkan, perusahaan $\mathrm{X}$ tergolong memiliki ukuran organisasi yang sedang. Penelitian yang dilakukan oleh Nafees (dalam Arif, Zubair, Manzoor, 2012) mengindikasikan bahwa terdapat perbedaan yang signifikan antara perilaku kerja inovatif yang muncul pada organisasi dengan ukuran sedang dan kecil. Organisasi yang berukuran sedang akan lebih sering memunculkan perilaku kerja inovatif dibandingkan organisasi yang berukuran kecil (Nafees, dalam Arid, Zubair, \& Manzoor, 2012). Hal ini dikarenakan ukuran perusahaan yang sedang maupun besar akan lebih memiliki banyak potensi-potensi untuk dikembangkan secara inovatif. Namun pada perusahaan $X$, walaupun perusahaan $\mathrm{X}$ tergolong dalam ukuran perusahaan sedang, masing- masing departemen yang ada justru cenderung memiliki kesamaan lingkup pekerjaan yang sama.

Pada penelitian ini, peneliti juga melakukan teknik analisa dengan menghitung perbedaan rata-rata pada kelompok berdasarkan enam aspek demografis. Aspek pertama yang memiliki perbedaan rata-rata kelompok yang signifikan pada perilaku kerja inovatif adalah jenis kelamin. Hal ini sesuai dengan penelitian Janssen (2000) yang mengatakan bahwa terdapat perbedaan rata-rata kelompok yang signifikan pada perilaku kerja inovatif berdasarkan jenis kelamin. Namun, hasil penelitian ini tidak sejalan dengan hasil penelitian Arif, Zubair, dan Manzoor (2012) yang menyatakan bahwa ditemukan indeks rata-rata kelompok yang lebih tinggi pada jenis kelamin perempuan akan perilaku kerja inovatif.

Aspek berikutnya adalah tingkat pendidikan. Berdasarkan hasil analisis statistik, responden dengan tingkat pendidikan magister memiliki rata-rata kelompok paling tinggi dibandingkan responden dengan tingkat pendidikan lainnya. Hal ini sejalan dengan penelitian yang dilakukan oleh Janssen (2000), Hammond, dkk. (2011), dan Oukes (2010) yang menyatakan bahwa semakin tinggi tingkat pendidikan responden, maka semakin tinggi pula kecenderungan seseorang untuk menampilkan perilaku kerja inovatif. Hal ini mungkin dikarenakan orang dengan tingkat pendidikan yang lebih tinggi akan dapat lebih mudah melihat peluang yang mana ia dapat menerapkan suatu inovasi baru pada peluang tersebut.

Aspek jabatan responden juga memiliki perbedaan rata-rata kelompok yang signifikan. Adanya korelasi yang signifikan antara tingkat jabatan dengan perilaku kerja inovatif sesuai dengan penelitian yang dilakukan oleh Scott dan 
Bruce (1994), namun, terdapat perbedaan hasil arah korelasi yang ada pada Scott dan Bruce (1994) dan pada penelitian ini. Penelitian ini memiliki arah dan signifikansi korelasi yang positif, sedangkan penelitian Scott dan Bruce (1994) menunjukkan adanya korelasi negatif pada tahapan karir dengan perilaku kerja inovatif. . Hasil yang positif antara jabatan dan perilaku kerja inovatif pada penelitian ini mungkin dikarenakan jabatan managerial lebih memiliki kebebasan dalam menunjukkan perilaku kerja inovatif dibandingkan karyawan dengan level jabatan non- managerial, sehingga pada akhirnya mereka lebih memiliki kecenderungan lebih besar dalam menampilkan perilaku kerja inovatif.

Aspek terakhir yang memiliki perbedaan rata-rata secara signifikan pada perilaku kerja inovatif adalah departemen. Departemen yang memiliki rata-rata skor total perilaku kerja inovatif yang paling tinggi adalah media services. Hal ini mungkin dikarenakan departemen media services merupakan departemen yang paling harus beradaptasi dengan kemajuan media terutama media digital yang terus berkembang. Seiring dengan pernyataan Carmeli dan Atwater (dalam Jafri, 2010) bahwa kecepatan perubahan dalam bidang teknologi serta meningkatnya persaingan dalam era globalisasi pada organisasi menuntut karyawannya untuk selalu dapat menciptakan ide baru serta memikirkan cara dan strategi yang berbeda agar dapat memperoleh keunggulan kompetitif diantara pasar yang ada.

\section{SIMPULAN}

Hasil penelitian menunjukkan tidak terdapat hubungan yang signifikan antara identitas organisasi dan perilaku kerja inovatif. Sementara itu, terdapat perbedaan rata-rata perilaku kerja inovatif berdasarkan data demografis responden, yaitu: jenis kelamin, pendidikan, jabatan dan departemen tempat bekerja.

\section{SARAN}

Pada penelitian selanjutnya, dapat diteliti kembali mengenai hubungan identitas organsisasi dan perilaku kerja inovatif. Hal ini dikarenakan penelitian mengenai hubungan kedua variabel ini masih sangat sedikit. Gawer dan Philips (2013) meneliti kedua hubungan variabel ini pada perusahaan Intel, sementara penelitian ini dilakukan pada konteks industri kreatif. Kedua penelitian ini pun menunjukkan hasil yang berbeda. Oleh karena itu, penelitian selanjutnya dapat meneliti mengenai hubungan kedua variabel ini dalam konteks perusahaan yang berbeda, sehingga didapatkan hasil penelitian yang lebih beragam. Selain itu, penelitian berikutnya juga dapat mengkontrol variabel budaya organisasi terutama budaya kekeluargaan. Sehingga diduga hubungan identitas organisasi dan perilaku kerja inovatif dapat semakin kuat ketika budaya organisasi terutama budaya kekeluargaan dikontrol.

Dari segi metodologis, peneliti menyarankan untuk turut menyertakan metode wawancara ataupun diskusi kelompok untuk mendapatkan data yang lebih komprehensif. Hal ini khususnya berkaitan dengan variabel identitas organisasi. Dengan menggunakan metode wawancara ataupun diskusi kelompok yang bersifat kualitatif, jawaban responden mengenai karakteristik organisasi yang dianggap utama, telah berlangsung secara terus menerus, dan berbeda dari organisasi lain dapat lebih diperoleh secara lebih dalam. Selain itu, agar didapatkan informasi lebih mendalam mengenai karakteristik sampel yang memiliki perbedaan rata-rata kelompok paling 
signifikan, penelitian selanjutnya diharapkan dapat melakukan analisis post-hoc pada perhitungan analisis data.

Dari segi praktis, peneliti memiliki beberapa saran terkait penelitian ini. Melihat bahwa perilaku kerja inovatif merupakan hal yang penting agar suatu organisasi dapat bertahan (Moon, 2014), organisasi perlu untuk mulai merencanakan bentuk intervensi yang dapat meningkatkan perilaku kerja inovatif. Rancangan intervensi dapat dibuat dengan fokus mempertimbangkan faktor-faktor yang memengaruhi perilaku kerja inovatif. Perusahaan $\mathrm{X}$ juga sebaiknya tidak memaksakan perilaku kerja inovatif sebagai salah satu aspek yang dinilai dalam performa penilaian kinerja. Hal ini dikarenakan perilaku kerja inovatif merupakan suatu peran kerja yang bersifat tambahan, yang tidak secara eksplisit disebutkan dalam lingkup pekerjaan dan juga tidak berhubungan dengan sistem reward (Katz, dalam Janssen, 2000).

Sebagaimana yang telah dipaparkan bahwa identitas organisasi dapat menjadi suatu panduan agar karyawan tahu perilaku apa yang tepat untuk ditunjukkan dalam organisasi (Gioia, Schultz, \& Corley, 2000), perusahaan $\mathrm{X}$ perlu untuk mulai merencanakan suatu hal yang dapat membuat karyawan paham dan memiliki persepsi yang tepat akan karakteristik organisasi yang dianggap utama, berlangsung secara terus-menerus, dan berbeda dari organisasi lain. Raymond (dalam Gawer \& Phillips, 2013) menyatakan bahwa pada awalnya, perlu dilakukan advokasi mengenai nilai-nilai organisasi. Menanggapi hal ini, Chesbrough (dalam Gawer \& Phillips, 2013) menyatakan bahwa penting untuk sering melakukan aktivitas yang dapat memfasilitasi karyawan untuk lebih paham dan lebih memaknai nilai-nilai yang ada. Ketika nilai tersebut telah dimaknai dan dipersepsi dengan baik oleh karyawan, maka karyawan pun akan lebih mudah menerapkan nilai-nilai tersebut dalam pekerjaan mereka seharihari. Berdasarkan hal tersebut, salah satu cara yang dapat dilakukan adalah adanya program orientasi pada karyawan baru yang mengenalkan karakteristik organisasi dan memperkuat karakteristik tersebut dengan menerapkannya dalam kegiatan sehari- hari.

\section{DAFTAR PUSTAKA}

Arif, S., Zubair, A., \& Manzoor, Y. (2012). Innovative Work Behavior and Communication Climate among Employees of Advertising Agencies. National Institute of Psychology Quaid-iAzam, 65-72.

Ashforth, B., \& Mael, F. (1996). Organizational Identity and Strategy as a Context Individual. Advances in Strategic Management, 13, 19-44.

Darwis, Y. (2013). The Urgency of Communication Media (ECommerce) in Indonesia's Creative Industry as an Effort to Increase International Business Competition: A Case Study of the Fashion Industry.

De Jong, J. P. J., \& Hartog, D. N. D. (2008). Innovative work behavior Measurement and validation. Scientific Analysis of Entrepreneurship and SMEs, 127.

Dhalla, R. (2007). The Construction of Organizational Identity: Keys contributing External and IntraOrganizational Factor. Corporate Reputation Review, 10(4), 245 260.

Dörner, N. (2012). Innovative work behavior: the roles of employee expectations And effects 
on job performance. University of St.Gallen, Dissertation no. 4007.

Etikariena, A. (Not Published). (Disertasi). Peran Memori Organisasi, Identitas Organisasi, dan Kesiapan Karyawan Berinovasi Terhadap Perilaku kerja inovatif. Universitas Indonesia, Depok.

Gawer, A., \& Phillips, N. (2013). Institutional Work as Logics Shift: The Case of Intel's Transformation to Platform Leader. United Kingdom: Sage Publications.

Gioia, D., Schultz, M., \& Corley, K. G. (2000), "Organizational Identity, Image and Adaptive Instability". Academy of Management Review. 25 (1), 63-81.

Harris, T.E. (2002). Applied Organizational Communication: Principles and Pragmatics for Future Practice (2nd ed.). United States of America: Lawrence Erlbaum Associates, Inc.

Hammond, M.M., Farr, J.L., Neff, N.L., Schwall, A.R., \& Zhao, X. (2011). Predictors of individual level of innovation at work: A meta analysis. Psychology of Aesthetics, Creativity, and the Arts, 5(1), 90-103.

Hoholm, T., \& Strønen, F. (2011). Innovation, Strategy, and Identity: A Case Study From the Food Industry. European Journal of Innovation Management, 14(3), 345-363.

Janssen, O. (2000). Job demands, perception of effort-reward fairness and innovative work behavior. Journal of Occupational and Organizational Psychology, 73(3), 287-302.
Kanter, R. (1988), When a thousand flowers bloom: structural, collective, and social conditions for innovation in organizations, in Staw, B.M. and Cummings, L.L. (Eds). Research in Organizational Behavior, 10, 169-211.

Kheng, Y, K., June, S., \& Mahmood, R. (2013). The determinants of innovative work behavior in the knowledge intensive business services sector in Malaysia. Asian Social Science, 9 (15), 4758.

Leong, C., \& Rasli, A., (2013). The Relationship Between Innovative Work Behavior on Work Role Performance: An Empirical Study. Social and Behavioral Sciences, 129, 592-600.

Lin, Y. (2004). Organizational Identity and Its Implication on Organizational Development. University of Minnesota, USA.

Oukes, T. (2010). Innovative Work Behavior: A Case Study at a Tire Manufacturer. University of Twente, Netherland.

Moore, I. (2014). Culture and Creative Industries Concept - a Historical Perspective. Social and Behavioral Sciences, 110, 738746.

Moon, T. (2014). Mentoring the Next Generation for Innovation in Today's Organization.

Journal of Strategic Leadership, 5(1), 23-35.

Parman, A., Subagiyo, Chairi, B., Erwidodo, Kresnarini, H, I., \& Suseno, E. (2008). Pengembangan Ekonomi Kreatif Indonesia 2025. Indonesia : Departemen Perdagangan Republik Indonesia. Diakses dari http://dgi-indonesia.com/wpcontent/uploads/2009/05/buku-1- 
rencana-pengembangan-

ekonomi-kreatif-indonesia2009.pdf

Schermuly, C., Meyer B., \& Dammer, L. (2013). Leader-Member

Exchange and Innovative Behavior. Journal of Personnel Psychology, 12(3), 132-142.

Scott, S.G., \& Bruce, R.A. (1994). Determinants of innovative behavior: A path model of individual innovation in the workplace. Academy of Management Journal, 37 (3), 580- 607.

Shalley, C.E., Zhou, J., \& Oldham, G.R. (2004). The effects of personal and and contextual characteristics on creativity: Where should we go from here. Journal of Management, 30(6), 933-958.

Tim Studi Ekonomi Kreatif, Kemenparekraf (2014). Artikel [on-line]. Diakses 15 Maret 2015 dari

http://program.indonesiakreatif.n et/research/kontribusi-ekonomikreatif-indonesia/

United Nation Confrence on Trade and Development. (2010). Creative Economy Report 2010. Diakses pada 2 April 2015 dari http://unctad.org/en/Docs/ditctab 20103_en.pdf
Utami, L. D., \& Lantu, D. C. (2014). Development competitiveness model for small medium enterprises among the creative industry in bandung. Social and Behavioral Sciences, 115, 305323.

Waenink, E. (2012). Creating innovation in employees, the effect of competences on innovative work behavior and the moderating role of human resources practices. (Master's Thesis). Universiteit Twente, Enschede.

Weick, K., Sutcliffe, K., \& Obstfeld, D., (2005). Organizing and the Process of Sensemaking. Organization Science, 16(4), 409-421.

West, M.A., \& Farr, J.L. (1989). Innovation at work: Psychological Perspectives. Social Behavior, 4, 15-30.

Whetten, D. (2006). Albert and Whetten: Strengthening the Concept of Organizational Identity. Journal of Management Inquiry, 15(3), 219-234.

Witting, M. (2006). Relations Between Organizational Identity, Identification, and Organizational Objectives: An Empirical Study in Municipalities. Universiteit Twente, Enschede. 